\title{
Taxonomy and Epidemiology of Gram-negative Bacterial Plasmids Studied by DNA-DNA Filter Hybridization in Formamide
}

\author{
By AGNES F. ROUSSEL AND YVES A. CHABBERT \\ Service de Bactériologie Médicale, Institut Pasteur, \\ 25 Rue du Docteur Roux, 75015 Paris, France
}

(Received 21 July 1977; revised 26 September 1977)

\begin{abstract}
Phylogenetic and epidemiological relatedness among transferable plasmids belonging to the IncC, IncM and IncH incompatibility groups has been studied by DNA-DNA filter hybridization. Hybridization was carried out on nitrocellulose microfilters, at low temperature, in formamide and under paraffin oil. The degree of hybridization among plasmids belonging to the IncC and IncM groups supported the conclusions drawn from genetic classification. Studies on relatedness among plasmids belonging to the $\mathrm{IncH}$ group allowed their classification into three phylogenetic sub-groups. Comparison of DNA sequences of three plasmids sharing the same genetic properties and isolated from different bacterial species suggested an epidemiological spread of the same plasmid.
\end{abstract}

\section{INTRODUCTION}

Plasmids responsible for the transfer of drug resistance and for metabolic markers have been divided into several classes on the basis of their ability to coexist stably with plasmids of other groups (Datta \& Hedges, 1971; Hedges \& Datta, 1971; Chabbert et al., 1972; Coetzee, Datta \& Hedges, 1972; Grindley, Grindley \& Anderson, 1972; Le Minor et al., 1976; Scavizzi, 1973). Molecular hybridization of nucleic acids has been used to establish phylogenetic relatedness between plasmid deoxyribonucleic acids, and in particular to determine whether any correlation exists with the classification obtained from genetic tests. Guerry \& Falkow (1971), Falkow (1975), Grindley, Humphreys \& Anderson (1973) and Smith et al. (1973) found that plasmids of the IncFI, IncFII, IncI1, IncI2, IncB and IncW groups showed considerable homology within their groups and that there was a much lower degree of homology between plasmids of different groups. An exception was observed within IncH plasmids by Anderson, Humphreys \& Willshaw (1975) and Grindley et al. (1973).

In the present study we wished to determine whether it was possible to extend these findings to two other groups of transferable plasmids which are frequently encountered, namely IncC (or Inc6) and IncM (or Inc7). We also studied the phylogenetic relatedness among isolated IncH plasmids harbouring resistance and metabolic markers. Secondly, we wished to survey the stability of some transferable plasmids belonging to the IncC group, and their epidemiological spread through different Enterobacteriaceae.

These molecular relatedness studies of IncC, IncM and $\mathrm{IncH}$ plasmids were carried out by adapting the hybridization technique recently described for RNA-DNA hybridization by Kourilsky et al. (1974), in which hybridization was performed on nitrocellulose microfilters, at low temperature, in formamide and under paraffin oil. 


\section{METHODS}

Plasmids and bacterial strains. The plasmids studied are listed in Table 1, together with their host strain, incompatibility group, antibiotic resistance and metabolic markers, transfer ability and the origin and year of isolation of the parental strain.

Strain BM21 (14R525 K-12 Escherichia coli, prototroph, nalidixic acid resistant), obtained from E. S. Anderson, was used as the bacterial host for all plasmids except those of group IncH. Strain BM03 (c600 $\mathrm{K}-12\left[\mathrm{~F}^{-}\right]$thr leu thi lac, rifampicin resistant) was used as the bacterial host for the group IncH plasmids. Neither strain harboured plasmids [R-].

Media and buffer solutions. For the preparation of labelled plasmid DNA, M9 liquid medium (Clowes \& Hayes, 1968) was used with glucose as sole carbon source; total unlabelled DNA was obtained from strains grown in Brain Heart Infusion (BHI, Difco). Buffer solutions were saline/EDTA (0.5 M-NaCl, $0.01 \mathrm{M}$-EDTA, $\mathrm{pH} 8.0)$, and $20 \times \mathrm{SSC}(3 \mathrm{M}-\mathrm{NaCl}, 0.3 \mathrm{M}$ tri-sodium citrate) filtered through a Millipore membrane.

Materials. Lysozyme was from Sigma; sodium lauryl sulphate (SLS) from Serlabo; RNAase (bovine pancreas) from Calbiochem; formamide ('proanalysis' grade) and proteinase $\mathbf{K}$ from Merck; phenol from Carlo Erba. Nitrocellulose membranes were Sartorius SM11306, $25 \mathrm{~mm}$ diam. [methyl- ${ }^{3} \mathrm{H}$ ]Thymidine, specific activity $42 \mathrm{Ci} \mathrm{mmol}^{-1}$, was purchased from the Commisseriat à l'Energie Atomique, France.

Isolation of labelled plasmid DNA by dye-buoyant density gradient centrifugation. Plasmid DNA was labelled by growing bacteria in $\mathrm{M} 9$ with $400 \mu \mathrm{Ci}$ of [ ${ }^{3} \mathrm{H}$ ] thymidine per $20 \mathrm{ml}$ culture to a density of $5 \times 10^{8}$ organisms $\mathrm{ml}^{\mathbf{1}}$. Plasmid DNA was then extracted as described by Ingram, Richmond \& Sykes (1973) except that an additional centrifugation to equilibrium in ethidium bromide-caesium chloride was used to eliminate any chromosomal DNA. Ethidium bromide was extracted with isopropanol saturated by Tris/EDTA (10 mM-Tris, $1 \mathrm{mm-EDTA,} \mathrm{pH} 7 \cdot 5)$ and the DNA solution was dialysed against at least $400 \mathrm{vol}$. Tris/EDTA. The DNA was sonicated for five periods of $30 \mathrm{~s}$ at $4{ }^{\circ} \mathrm{C}$ in a M.S.E. sonic oscillator at maximum power and concentrated by ethanol precipitation at $-20^{\circ} \mathrm{C}$. This preparation gave plasmid DNA with specific activities ranging from $5 \times 10^{4}$ to $1 \times 10^{5}$ c.p.m. $\mu \mathrm{g}^{-1}$ and yielded DNA fragments estimated from electron microscopy to have molecular weights of about $6 \times 10^{5}$.

Preparation of unlabelled 'total' cell DNA. Bacteria were grown at $37^{\circ} \mathrm{C}$ in $10 \mathrm{ml} \mathrm{BHI}$ to a density of $5 \times 10^{8}$ organisms $\mathrm{ml}^{-1}$. Cells were washed with saline/EDTA and the pellet was resuspended in $1 \mathrm{ml}$ saline/EDTA containing $1 \mathrm{mg}$ lysozyme and $0.5 \mathrm{mg}$ RNAase (DNAase-free). Cells were lysed by adding $50 \mu 120 \%(\mathrm{w} / \mathrm{v})$ sodium lauryl sulphate, and the lysate was treated overnight at room temperature with proteinase K (predigested for $2 \mathrm{~h}$ ) at a final concentration of $100 \mu \mathrm{g} \mathrm{ml}^{-1}$ (Kourilsky, personal communication). DNA purification and deproteinization were carried out with two saline/EDTA/saturated phenol extractions followed by two chloroform/isoamyl alcohol $(24: 1, \mathrm{v} / \mathrm{v})$ extractions. The final supernatant was precipitated overnight with 2 vol. cold $95 \%(\mathrm{v} / \mathrm{v})$ ethanol at $-20^{\circ} \mathrm{C}$. Pelleted DNA was resuspended

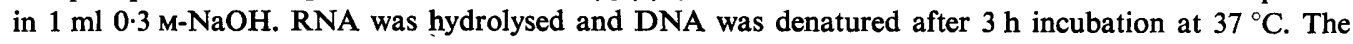
denatured DNA solution was neutralized by adding $0.2 \mathrm{ml} 2 \mathrm{M}-\mathrm{NaH}_{2} \mathrm{PO}_{4}$ and quenched in ice; $20 \times \mathrm{SSC}$ and water were then added to achieve a final concentration of $2 \mu \mathrm{g} \mathrm{ml}^{-1}$ in $4 \times \mathrm{SSC}$. The diphenylamine procedure (Shatkin, 1969) was used for the titration of denatured DNA solution. This solution was immediately used for the preparation of DNA filters.

\section{DNA-DNA hybridization}

The procedure used was an adaptation of the techniques described by Kourilsky, Leidner \& Tremblay (1971) and by Kourilsky et al. (1974). For each hybridization experiment four kinds of filters were prepared: filters loaded with chromosomal DNA without plasmid DNA (called R-filters); filters with chromosomal DNA and homologous plasmid DNA ( $\mathrm{R}^{+}$hom filters); filters with chromosomal DNA and heterologous plasmid DNA ( $\mathrm{R}^{+}{ }_{\text {het }}$ filters); and filters without any DNA (blank filters).

Preparation of DNA filters. The filters were presoaked in $4 \times \mathrm{SSC}$ for at least $10 \mathrm{~min}$. Alkali-denatured DNA was fixed to nitrocellulose filters ( 0 to $100 \mu \mathrm{g}$ per $25 \mathrm{~mm}$ diam. filter) by slow filtration through the membrane ( $5 \mathrm{ml} \mathrm{min}^{-1}$; Denhardt, 1966). DNA and blank filters were washed with $4 \times \mathrm{SSC}$ pH 7.0 followed by $0.5 \times \mathrm{SSC} \mathrm{pH} \mathrm{7.0,} \mathrm{and} \mathrm{then} \mathrm{placed} \mathrm{on} \mathrm{blotting} \mathrm{paper} \mathrm{and} \mathrm{dried.} \mathrm{They} \mathrm{were} \mathrm{desiccated} \mathrm{overnight} \mathrm{over}$ silica gel at room temperature, then placed in plastic Petri dishes in a vacuum desiccator for $2 \mathrm{~h}$ at $80^{\circ} \mathrm{C}$ (Gillespie \& Spiegelman, 1965). Dry filters could be stored in a vacuum desiccator at $4^{\circ} \mathrm{C}$ for 1 month.

Preparation of the annealing labelled mixture. The labelled plasmid DNA, treated as described above, was resuspended in 1 vol. $0 \cdot 1 \times \mathrm{SSC}$, denatured by $0.1 \mathrm{vol}$. $1 \mathrm{M}-\mathrm{NaOH}$ for $15 \mathrm{~min}$ at $4{ }^{\circ} \mathrm{C}$ and then neutralized with $0 \cdot 1$ vol. $2 \mathrm{M}-\mathrm{NaH}_{2} \mathrm{PO}_{4} ; 20 \times \mathrm{SSC}$ and formamide were added to give final concentrations of $2 \times \mathrm{SSC}$ and $50 \%(\mathrm{v} / \mathrm{v})$ formamide. The total volume was calculated to obtain 300 to 500 c.p.m. per $4 \mu \mathrm{l}$ in the final annealing mixture. 
Table 1. Plasmids and their origins

\begin{tabular}{|c|c|c|c|c|c|c|}
\hline Strain* & $\begin{array}{l}\text { Plasmid } \\
\text { no.* }\end{array}$ & $\begin{array}{l}\text { Incom- } \\
\text { patibility } \\
\text { group }\end{array}$ & Phenotypic characte & erst & Origin & Reference \\
\hline BM273 & pIP55 & IncC & $\mathrm{ApGmTmCmSu}$ & $\mathrm{Fi}^{-}$ & $\begin{array}{l}\text { Klebsiella pneumoniae } \\
\text { 35, Paris } 1969\end{array}$ & Witchitz \& Chabbert, 1971 \\
\hline BM299 & pIP64 & IncC & $\mathrm{ApGmTmCmSu}$ & $\mathrm{Fi}^{-}$ & $\begin{array}{l}\text { Pseudomonas aeruginosa, } \\
\text { Paris } 1969\end{array}$ & , Witchitz \& Chabbert, 1972 \\
\hline BM4001 & pIP149 & IncC & $\mathrm{ApGmTmCmSu}$ & $\mathrm{Fi}^{-}$ & $\begin{array}{l}\text { K. pneumoniae, Paris } \\
1972\end{array}$ & Witchitz, 1977 \\
\hline BM4002 & pIP150 & IncC & $\mathrm{SmGmCmSu}$ & $\mathrm{Fi}^{-}$ & $\begin{array}{l}\text { K. pneumoniae, Paris } \\
1972\end{array}$ & Witchitz, 1977 \\
\hline BM275 & pIP16a & IncC & $\mathrm{ApKmSu}$ & $\mathrm{Fi}^{-}$ & $\begin{array}{l}\text { Providencia stuartii, } \\
\text { Paris } 1966\end{array}$ & Chabbert et al., 1972 \\
\hline BM300 & pIP153 & IncC & $\mathrm{ApSmKmCmTcSu}$ & $\mathrm{Fi}^{-}$ & $\begin{array}{l}\text { Vibrio cholerae El tor, } \\
\text { Algeria } 1972\end{array}$ & $\begin{array}{l}\text { Rahal, Gerbaud \& Chab- } \\
\text { bert. } 1973\end{array}$ \\
\hline BM4004 & pIP151 & IncM & $\mathrm{SmGmTcSu}$ & $\mathrm{Fi}^{-}$ & $\begin{array}{l}\text { K. pneumoniae, Paris } \\
1972\end{array}$ & Witchitz, 1977 \\
\hline BM279 & pIP135 & IncM & $\mathrm{SmGmTcSu}$ & $\mathrm{Fi}^{-}$ & $\begin{array}{l}\text { Enterobacter cloacae, } \\
\text { Paris } 1971\end{array}$ & Witchitz \& Gerbaud, 1972 \\
\hline BM276 & pIP69 & IncM & $\mathrm{ApKm} \mathrm{Tc}$ & $\mathrm{Fi}^{-}$ & $\begin{array}{l}\text { Salmonella paratyphi } \mathrm{B}, \\
\text { Créteil } 1969\end{array}$ & Chabbert et al., 1972 \\
\hline BM4005 & pIP56a & $\ddagger$ & $\mathrm{ApGmTmCmSu}$ & $\mathrm{Fi}^{+}$ & $\begin{array}{l}\text { Escherichia coli, Paris } \\
1969\end{array}$ & Witchitz \& Chabbert, 1972 \\
\hline BM251 & pIP162 & IncFI & $\mathrm{ApSmCm} \mathrm{TcSu}$ & $\mathrm{Fi}^{+}$ & $\begin{array}{l}\text { Salmonella typhi, } \\
\text { France } 1973\end{array}$ & Chabbert \& Gerbaud, 1974 \\
\hline BM301 & $\mathrm{R} 1-19 \mathrm{~K}^{-}$ & IncFII & $\mathrm{ApSmCmSu}$ & $\mathrm{Fi}^{+}$ & $\begin{array}{l}\text { S. paratyphi B, England } \\
1964\end{array}$ & Grindley et al., 1973 \\
\hline BM271 & RSa & IncW & $\mathrm{SmKmCmSu}$ & $\mathrm{Fi}^{-}$ & Shigella, Japan & Hedges \\
\hline BM269 & pIP113 & IncN & Tc & $\mathrm{Fi}^{-}$ & $\begin{array}{l}\text { Salmonella panama, } \\
\text { Paris } 1968\end{array}$ & Chabbert et al., 1972 \\
\hline $\begin{array}{l}\text { BM261 } \\
\text { BM436 }\end{array}$ & $\begin{array}{l}\text { pIP112 } \\
\text { TP123(T-) }\end{array}$ & $\begin{array}{l}\text { IncI1 } \\
\text { IncH1 }\end{array}$ & $\begin{array}{l}\mathrm{Km} \mathrm{Cib} \\
\mathrm{SmCmSu}\end{array}$ & $\mathrm{Fi}^{-}$ & S. panama, Paris 1968 & Chab \\
\hline BM439 & TP116 & IncH2 & $\mathrm{SmCmSu}$ & $\mathrm{Fi}^{-}$ & $\begin{array}{l}\text { S. typhi, Mexico } 1972 \\
\text { S. typhi, Spain } 1969\end{array}$ & $\begin{array}{l}\text { Anderson et al., } 1975 \\
\text { Anderson } \text { et al., } 1975\end{array}$ \\
\hline BM4006 & pIP165 & IncH & $\mathrm{SmCmTcSu}$ & $\mathrm{Fi}^{-}$ & S. typhi, Mexico 1973 & Chabbert \& Gerbaud, 1974 \\
\hline BM4007 & pIP166 & IncH & $\mathrm{SmCmTcSu}$ & $\mathrm{Fi}^{-}$ & S. typhi, Vietnam 1973 & Chabbert \& Gerbaud, 1974 \\
\hline BM437 & pIP5228 & IncH & $\mathrm{SmCmSu}$ & $\mathrm{Fi}^{-}$ & S. typhi, Vietnam 1973 & Chabbert \& Gerbaud, 1974 \\
\hline BM440 & MIP233 & IncH & Sac & $\mathrm{Fi}^{-}$ & $\begin{array}{l}\text { Salmonella ohio, } \\
\text { London } 1972\end{array}$ & Le Minor et al., 1976 \\
\hline & MIP235 & IncH & Lac & $\mathrm{Fi}^{-}$ & $\begin{array}{l}\text { Salmonella oranienburg, } \\
\text { Sao Paulo } 1973\end{array}$ & $\begin{array}{l}\text { Buissiere, Coynault \& } \\
\text { Le Minor, } 1977\end{array}$ \\
\hline
\end{tabular}

* The nomenclature used for strains and plasmids follows Novick et al. (1976). Plasmid-containing strains BM273 to BM261 were derived from strain BM21 and strains BM436 to BM4008 from strain BM03.

$\dagger$ Symbols for phenotypic characters. Antibiotic resistances: Ap, ampicillin; Cm, chloramphenicol; Sm, streptomycin; Km, kanamycin; Gm, gentamicin; Tm, tobramycin; Tc, tetracycline; Su, sulphonamide. $\mathrm{Fi}^{+}$, inhibition of conjugational transfer mediated by the plasmid; $\mathrm{Fi}^{-}$, lack of inhibition of conjugational transfer. Lac, Sac, ability to metabolize lactose, saccharose. Cib, production of colicin Ib.

‡ Compatible with all reference plasmids.

$\S$ pIP522 was pIP166/1 (Chabbert \& Gerbaud, 1974), a segregant of pIP166.

DNA-DNA hybridization in paraffin. Microfilters $(5 \mathrm{~mm}$ diam.) were punched out of the large loaded filters (eight microfilters per $25 \mathrm{~mm}$ diam. filter). After numbering the microfilters, $4 \mu \mathrm{l}$ of the reaction mixture was placed on each one and they were immediately coated with paraffin oil and incubated overnight in paraffin oil at $37^{\circ} \mathrm{C}$.

Washing procedure. After incubation the filters were taken out of the oil bath and paraffin oil was removed by wiping them with blotting paper. They were washed together twice (45 and $10 \mathrm{~min}$ ) in a $0.1 \% \mathrm{SLS} / 50 \%$ formamide $/ 2 \times \mathrm{SSC} \mathrm{pH} 7.0$ bath with magnetic stirring (about 100 microfilters in a $500 \mathrm{ml}$

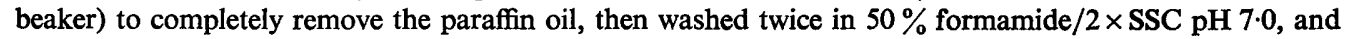
finally rapidly rinsed in $2 \times \mathrm{SSC} \mathrm{pH} 7.0$ before drying on blotting paper. The amount of ${ }^{8} \mathrm{H}$-labelled DNA bound to each microfilter was determined by a $10 \mathrm{~min}$ count in an Intertechnique liquid scintillation spectrometer. 


\section{RESULTS}

\section{Methodology}

Hydridization conditions and controls. Non-specific binding of labelled plasmid DNA to filters was tested for each hybridization by using blank filters. In $2 \times \mathrm{SSC} / 50 \%$ formamide, counts were not significantly different from the background of the scintillation spectrometer.

Leaking of DNA was tested by using labelled bacterial DNA bound to filters, incubated and washed as usual. Up to $95 \%$ was retained when solutions were adjusted to $\mathrm{pH} 7 \cdot 0$ $( \pm 0.5)$ throughout the entire process; this percentage was obtained regardless of the amount of denatured DNA bound from 1 to $100 \mu \mathrm{g}$.

Figure 1 shows a DNA saturation curve for hybridization of a constant amount of labelled plasmid DNA with increasing amounts of homologous unlabelled DNA. From this, we determined the amount of total denatured DNA which had to be used in order to provide an excess of binding sites. Nitrocellulose filters $(25 \mathrm{~mm}$ diam.) were loaded with $60 \mu \mathrm{g}$ of total denatured DNA and reassociation was performed with 0.005 to $0.01 \mu \mathrm{g}$ of labelled DNA in $4 \mu \mathrm{l}$ of annealing mixture (at $37^{\circ} \mathrm{C}$, in $2 \times \mathrm{SSC} / 50 \%$ formamide for $18 \mathrm{~h}$ ). The saturation curves obtained (Fig. 1) indicated that hybridization was nearly exhaustive. Under these conditions, the efficiency of hybridization ranged from 85 to $95 \%$. The binding of labelled plasmid DNA to $\mathrm{R}^{-}$filters ranged from 5 to $15 \%$ of the total binding to $\mathrm{R}^{+}$hom filters when the additional purification of plasmid supercoiled DNA was performed.

Measurement of plasmid homology. The values reported in Tables 2, 3 and 4 indicate the degree of reassociation, $\alpha_{\mathrm{M}}$, in $2 \times \mathrm{SSC} / 50 \%$ formamide between homologous labelled plasmid DNA and unlabelled filter-bound plasmid DNA. $\alpha_{i}$ (percentage of homology) is defined as:

$$
\alpha_{\mathrm{i}}=\frac{\text { (counts bound to } \left.\mathrm{R}^{+}{ }_{\text {het }} \text { filters }\right)-\left(\text { counts bound to } \mathrm{R}^{-} \text {- filters }\right)}{\left(\text { counts bound to } \mathrm{R}^{+}{ }_{\text {hom }} \text { filters }\right)-\left(\text { counts bound to } \mathrm{R}^{-} \text {- filters }\right)} \times 100
$$

The reported values of $\alpha_{\mathrm{M}}$ ( \pm standard deviation) are the means of at least eight $\alpha_{\mathrm{i}}$ determinations obtained by hybridrizing $4 \mu \mathrm{l}$ from the same annealing mixture with eight (or more) filters of the three kinds used $\left(\mathrm{R}^{+}{ }_{\text {hom }}, \mathrm{R}^{+}{ }_{\text {het }}\right.$ and $\mathrm{R}^{-}$filters).

\section{Taxonomy of bacterial plasmids}

Homology among plasmids from different incompatibility groups. Table 2 shows the results of hybridization between plasmids belonging to the same incompatibility group (IncC or IncM group) and between plasmids belonging to different incompatibility groups (IncC or IncM plasmids with IncW, IncN, IncI1, IncFI or IncFII plasmids). The percentage of reassociation among plasmids belonging to the same group ranged from 66 to $100 \%$ whereas it was generally less than $15 \%$ between plasmids of different groups.

Homology among plasmids of the IncH group. Transferable resistance plasmids pIP165, pIP166 and pIP522 and metabolic plasmid MIP235, all belonging to the incompatibility group IncH, showed a very high percentage of reassociation with either TP123 or TP116 (reference plasmids from E. S. Anderson) but never with both (Table 3). These plasmids could therefore be classified into two subgroups: IncH1 and IncH2 (Table 3). Plasmids from group IncH1 (pIP165, pIP166, pIP522) showed a very close homology with TP123 and a very poor one with TP116 and MIP235. A notable exception was plasmid MIP233 which showed very poor homology with both IncH1 and IncH2 plasmids despite a strong incompatibility with them (Le Minor et al., 1976).

Study of pIP56a, a plasmid compatible with all reference plasmid groups. pIP56a is a naturally occuring plasmid compatible with all reference plasmids (Witchitz \& Chabbert, 1972; Witchitz, 1977), showing a positive fertility inhibition and the same multiresistance sequence Ap Gm Tm Cm Su as the series of IncC plasmids described below. pIP56a plasmid 


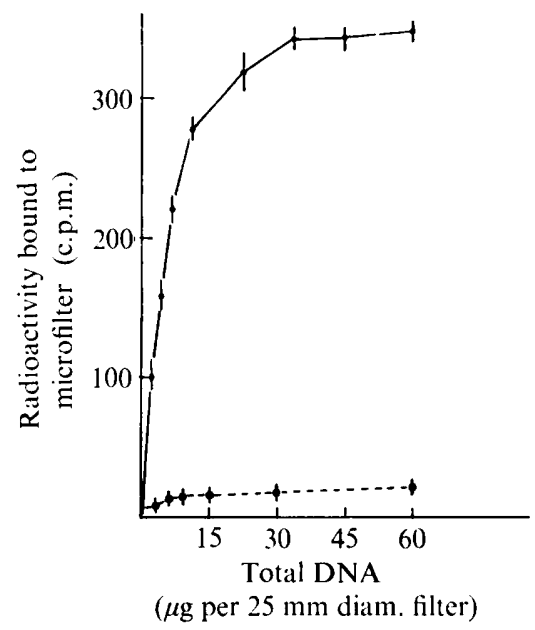

Fig. 1. Saturation curve of pIP55. Nitrocellulose filters $(25 \mathrm{~mm}$ diam.) were loaded with increasing amounts of denatured total DNA. Microfilters $(5 \mathrm{~mm}$ diam.) were punched and incubated with about $0.005 \mu \mathrm{g}$ of previously sonicated and denatured ${ }^{3} \mathrm{H}$-labelled pIP55 plasmid DNA. Reassociation was performed in $2 \times \mathrm{SSC} / 50 \%$ formamide at $37^{\circ} \mathrm{C}$ for $18 \mathrm{~h}$, under paraffin oil. -O, reassociation between pIP55 and total DNA of strain BM273(pIP55); -.- , reassociation between pIP55 and total DNA of strain BM21(R-). Bars represent $95 \%$ sampling error confidence limit. In these experiments, a plateau was obtained with an efficiency of $95 \%$.

Table 2. Homology among plasmids from different incompatibility groups

Nitrocelluose filters ( $25 \mathrm{~mm}$ diam.) were loaded with $60 \mu \mathrm{g}$ of total denatured DNA and reassociation was performed as indicated in Fig. 1. The results indicate the percentage of reassociation of ${ }^{3} \mathrm{H}$-labelled plasmid DNA with unlabelled plasmid DNA relative to the reassociation with both homologous plasmid DNA and with $E$. coli chromosomal DNA. These values, $\alpha_{M}( \pm$ standard deviation), were the mean of at least eight $\alpha_{i}$ determinations where $\alpha_{i}$ is defined as:

$$
\alpha_{i}=\frac{\text { (counts bound to } R^{+}{ }_{\text {het }} \text { filters) }- \text { (counts bound to } R^{-} \text {filters) }}{\text { (counts bound to } R^{+} \text {hom filters) }- \text { (counts bound to } R^{-} \text {filters) }} \times 100
$$

Total unlabelled

DNA from:

\begin{tabular}{|c|c|c|c|c|c|c|c|c|}
\hline \multirow{2}{*}{$\begin{array}{l}\text { Incom- } \\
\text { patibility } \\
\text { group }\end{array}$} & \multirow{2}{*}{$\begin{array}{c}\text { Plasmid } \\
\text { no. }\end{array}$} & \multicolumn{7}{|c|}{ Percentage of reassociation with labelled plasmid DNA from: } \\
\hline & & pIP55 & pIP150 & pIP16a & plP153 & pIP151 & pIP135 & pIP69 \\
\hline $\begin{array}{l}\text { IncC } \\
\text { IncC } \\
\text { IncC } \\
\text { IncC }\end{array}$ & $\begin{array}{l}\text { pIP55 } \\
\text { pIP150 } \\
\text { pIP16a } \\
\text { pIP153 }\end{array}$ & \begin{tabular}{|r}
$100 \pm 4$ \\
$77 \pm 5$ \\
$82 \pm 2$ \\
$83 \pm 3$ \\
\end{tabular} & $\begin{array}{r}89 \pm 2 \\
100 \pm 3 \\
74 \pm 2 \\
76 \pm 3 \\
\end{array}$ & $\begin{array}{r}78 \pm 2 \\
79 \pm 2 \\
100 \pm 3 \\
73 \pm 1 \\
\end{array}$ & $\begin{array}{r}74 \pm 2 \\
79 \pm 2 \\
66 \pm 1 \\
100 \pm 3 \\
\end{array}$ & $\begin{array}{l}5 \pm 1 \\
- \\
-\end{array}$ & $\begin{array}{l}\text { - }^{*} \\
-\end{array}$ & $\frac{-}{-}$ \\
\hline $\begin{array}{l}\text { IncM } \\
\text { IncM } \\
\text { IncM }\end{array}$ & $\begin{array}{l}\text { pIP151 } \\
\text { pIP135 } \\
\text { pIP69 }\end{array}$ & $\begin{array}{c}10 \pm 2 \\
5 \pm 1\end{array}$ & - & - & - & $\begin{array}{r}100 \pm 2 \\
97 \pm 3 \\
80 \pm 1 \\
\end{array}$ & $\begin{array}{r}100 \pm 6 \\
100 \pm 5 \\
81 \pm 5\end{array}$ & $\begin{array}{r}88 \pm 2 \\
87 \pm 2 \\
100 \pm 4 \\
\end{array}$ \\
\hline $\begin{array}{l}\text { IncW } \\
\text { IncN } \\
\text { IncI1 } \\
\text { IncFI } \\
\text { IncFII }\end{array}$ & $\begin{array}{l}\text { RSa } \\
\text { pIP113 } \\
\text { pIP112 } \\
\text { plP162 } \\
\text { R1-19K- }\end{array}$ & $\begin{array}{r}7 \pm 3 \\
0 \pm 2 \\
0 \pm 3 \\
10 \pm 3 \\
17 \pm 2\end{array}$ & $\begin{array}{c}- \\
- \\
-\end{array}$ & $\begin{array}{l}- \\
- \\
-\end{array}$ & $\begin{array}{l}- \\
- \\
-\end{array}$ & $\begin{array}{r}5 \pm 1 \\
5 \pm 1 \\
6 \pm 1 \\
12 \pm 1 \\
13 \pm 1\end{array}$ & $\begin{array}{l}- \\
- \\
- \\
-\end{array}$ & $\begin{array}{l}- \\
- \\
-\end{array}$ \\
\hline
\end{tabular}

DNA showed significant hybridization both with $\mathrm{Fi}^{+}$plasmids and with the group IncC plasmids pIP55 and pIP150 (Table 4). Assuming the molecular weights of pIP55 and pIP56a to be 105 and 41 respectively (P. Bennett, personal communication), the pIP55pIP56a crossed hybridization showed that the two plasmids shared common DNA sequences 
Table 3. Homology among plasmids of the IncH group

The procedures and expression of results are the same as those described in the legend to Table 2.

Total unlabelled DNA from:

$\begin{array}{cc}\text { Sub-group } & \text { Plasmid no. } \\ \text { IncH1 } & \text { TP123* } \\ \text { IncH1 } & \text { pIP166 } \\ \text { IncH1 } & \text { pIP522 } \\ \text { IncH1 } & \text { pIP165 } \\ \text { IncH2 } & \text { TP116* } \\ \text { IncH2 } & \text { MIP235 }\end{array}$

MIP233

\section{Phenotypic}

markers

$\mathrm{SmCmSu}$

$\mathrm{SmCm} \mathrm{TcSu}$

$\mathrm{SmCmSu}$

$\mathrm{SmCm} \mathrm{TcSu}$

$\mathrm{SmCmSu}$

$\mathrm{Lac} \mathrm{SmCmSu}$

Sac
Percentage of reassociation with labelled plasmid DNA from:

\begin{tabular}{|c|c|c|c|}
\hline TP123 & TP116 & MIP235 & MIP233 \\
\hline $\begin{array}{r}100 \pm 3 \\
91 \pm 3 \\
81 \pm 3 \\
92 \pm 3 \\
\end{array}$ & $\begin{array}{r}14 \pm 3 \\
5 \pm 2 \\
- \\
5 \pm 1\end{array}$ & $\begin{array}{c}14 \pm 4 \\
6 \pm 3 \\
- \\
-\end{array}$ & $\begin{array}{l}0 \pm 1 \\
1 \pm 1 \\
\overline{3 \pm 1}\end{array}$ \\
\hline $\begin{array}{r}5 \pm 1 \\
14 \pm 1\end{array}$ & $\begin{array}{r}100 \pm 6 \\
93 \pm 6 \\
\end{array}$ & $\begin{array}{r}86 \pm 3 \\
100 \pm 3 \\
\end{array}$ & $\begin{array}{l}5 \pm 1 \\
6 \pm 1\end{array}$ \\
\hline $3 \pm 2$ & $7 \pm 3$ & - & $100 \pm 5$ \\
\hline
\end{tabular}

* TP123 and TP116 are reference plasmids for H1 and H2 groups, respectively, obtained from E.S. Anderson.

Table 4. Study of pIP56a: a plasmid compatible with all reference plasmid groups

The procedures and expression of results are the same as those described in the legend to Table 2.

Total unlabelled DNA from:

\begin{tabular}{|c|c|c|c|}
\hline $\begin{array}{l}\text { Incompatibility } \\
\text { group }\end{array}$ & Plasmid no. & \multicolumn{2}{|c|}{ Phenotypic markers } \\
\hline$?$ & pIP56a & Ap GmTm $\mathrm{CmSu}$ & $\mathrm{Fi}^{+}$ \\
\hline IncC & pIP55 & Ap GmTm CmSu & $\mathrm{Fi}^{-}$ \\
\hline IncC & pIP150 & $\mathrm{Sm} \mathrm{GmCmSu}$ & $\mathrm{Fi}^{-}$ \\
\hline IncFI & pIP162 & $\mathrm{ApSmCm} \mathrm{TcSu}$ & $\mathrm{Fi}^{+}$ \\
\hline IncFII & R1-19K- & $\mathrm{ApSmCmSu}$ & $\mathrm{Fi}^{+}$ \\
\hline
\end{tabular}

Percentage of reassociation with labelled plasmid DNA from:

$\begin{array}{rr}\text { pIP56a } & \text { pIP55 } \\ 100 \pm 6 & 16 \pm 1 \\ 42 \pm 5 & 100 \pm 2 \\ 40 \pm 4 & 77 \pm 5 \\ 25 \pm 1 & 10 \pm 3 \\ 29 \pm 1 & 17 \pm 2\end{array}$

equivalent to 26 kilobases (as $105 \times 0 \cdot 16=41 \times 0 \cdot 42=17 \mathrm{Mdal}$ ). By a similar calculation, DNA sequences common to pIP56a and $\mathrm{Fi}^{+}$plasmids amounted to about 15 kilobases.

\section{Epidemiological survey of bacterial plasmids}

The degree of relatedness of plasmids pIP55, pIP64 and pIP149 was studied by the same hybridization technique. They were selected from a series of plasmids, described by Witchitz \& Chabbert (1972), which shared the following genetic properties: (i) they belong to incompatibility group IncC; (ii) they coded for associated resistance to kanamycin $(\mathrm{Km})$, gentamicin $(\mathrm{Gm})$ and tobramycin $(\mathrm{Tm})$ controlled by an aminoglycoside 2 "-adenylyltransferase (Witchitz, 1975); (iii) the $\mathrm{Gm}$ character was always associated with other characters Ap Cm Su coding, respectively, for ampicillin-carbenicillin, chloramphenicol and sulphonamide resistances.

The results of crossed hybridization between pIP55 from Klebsiella pneumoniae serotype 35, isolated in 1969, and pIP64 isolated 1 month later from Pseudomonas aeruginosa (Witchitz \& Gerbaud, 1972) showed a very close homology between these two plasmids $(99 \pm 3 \%$ in both crossed hybridization experiments). Percentages of reassociation observed between pIP55 or pIP64 ${ }^{3} \mathrm{H}$-labelled plasmid DNA and total unlabelled pIP149 DNA (from $K$. pneumoniae serotype 68 , isolated 3 years later), amounted in both cases to $100 \pm 4 \%$, whereas pIP149 ${ }^{3} \mathrm{H}$-labelled plasmid DNA showed $87 \pm 1$ and $88 \pm 1 \%$ of reassociation, respectively, with pIP55 and pIP64. These results indicated that the whole pIP55 DNA sequence was present in pIP64 and pIP149 plasmid DNAs. The fact that a significant fraction of pIP149 was not found to be present in pIP55 and pIP64 DNAs suggested that pIP149 had acquired additional DNA sequences. 


\section{DISCUSSION}

In addition to the various practical advantages which led us to choose the microfilter hybridization technique in formamide which is particularly useful and convenient to perform a large number of DNA hybridization assays, the very high efficiency of reassociation ( 85 to $95 \%$ ) indicated that the kinetics were optimal and that the hybridization reaction was exhaustive. Moreover the very low degree of radioactivity bound to filters loaded with chromosomal DNA [5\% when extensive purification of plasmid DNA was carried out (Fig. 1)] and the slopes obtained at the plateaus led us to conclude that the mismatching generally observed using formamide at low temperature was not too high in our conditions of hybridization.

The comparison of plasmid DNA sequences within and between incompatibility groups provided three main results.

(1) Hybridization within group IncC and IncM plasmids and reference plasmids of other groups correlate with the results obtained by Guerry \& Falkow (1971), Grindley et al. (1973) and Falkow (1975), using other techniques. Plasmids from the same incompatibility group showed a high degree of homology, but there was little homology among plasmids from different groups. The high degree of homology among plasmids of the same group probably reflected phylogenetic relationships.

(2) The peculiarities of group IncH plasmids have already been described by Grindley et al. (1973) and Anderson et al. (1975). With the exception of MIP233, all the IncH plasmids which we studied could be classified by the molecular hybridization technique into the IncH1 or IncH2 subgroups, according to Anderson's definition. The results observed with MIP233, a plasmid strongly incompatible with all IncH plasmids (Le Minor et al., 1976), might allow the characterization of a new phylogenetic sub-group IncH3. These findings reflected some diversity between the genetic structure of plasmids belonging to the IncH group.

(3) Plasmid pIP56a, carrying the Ap Gm Tm CmSu resistance markers associated with an $\mathrm{Fi}^{+}$expression, was compatible with all reference plasmids. Since it had been isolated from $E$. coli in a peritoneal dialysis liquid infected with three other species of bacteria, each harbouring an IncC Fi- Ap Gm Tm CmSu plasmid (Witchitz \& Chabbert, 1972), it might have resulted from recombination between an $\mathrm{Fi}^{+}$plasmid and an IncC $\mathrm{Fi}^{-}$ ApGmTmCmSu plasmid. The molecular hybridization studies showed a significant reassociation of pIP56a with both $\mathrm{Fi}^{+}$plasmids and group IncC plasmids, confirming the hypothesis that pIP56a was a natural composite plasmid resulting from interactions between several plasmids. However, incompatibility tests previously performed and the amount of homology observed did not allow assignment of pIP56a to either supposed parental incompatibility group (IncC, IncFI or IncFII).

A large number of exchange mechanisms described in molecular studies of plasmids (such as legitimate and illegitimate recombinations, transposition, associations and dissociations of plasmids) seem to indicate that plasmids might be considered as labile aggregates of genetic fragments. Nevertheless, genetic and physical studies of natural plasmids showed common and stable properties (incompatibility, fertility inhibition expression, transfer functions) which are generally correlated with a high degree of homology between DNA sequences. These observations allowed the classification of transferable plasmids into distinct phylogenetic entities and introduced the concept of 'plasmid species' (Falkow, 1975).

The appearance and the dissemination of the peculiar gentamicin resistance marker, always associated with $\mathrm{Ap} \mathrm{Gm} \mathrm{Tm} \mathrm{Cm} \mathrm{Su}$, and the genetic properties of plasmids harbouring these resistance genes (Witchitz \& Gerbaud, 1972; Witchitz, 1977), suggested an epidemiological spread and this is supported by the results of hybridization between these plasmids. 
We thank Ph. Kourilsky and D. Blangy for their interest in this work, their helpful discussions and their critical reading of the manuscript.

\section{REFERENCES}

Anderson, E. S., Humphreys, G. O. \& Willshaw, A. (1975). The molecular relatedness of $R$ factors in enterobacteria of human and animal origin. Journal of General Microbiology 91, 376-382.

Buissiere, J., Coynault, C. \& Le Minor, L. (1977). Etude des conditions d'expression du caractère raffinose chez $E$. coli et Salmonella. Annales de Microbiologie (Institut Pasteur) 128A, 167-183.

Chabbert, Y. A. \& Gerbaud, G. R. (1974). Surveillance épidémiologique des plasmides responsables de la résistance au chloramphénicol de Salmonella typhi. Annales de Microbiologie (Institut Pasteur) 125A, 153-166.

Chabbert, Y. A., Scavizzi, M. R., Witchitz, J. L., Gerbaud, G. R. \& Bouanchaud, D. H. (1972). Incompatibility groups and the classification of $\mathrm{Fi}^{-}$resistance factors. Journal of Bacteriology 112, 666-675.

Clowes, R. C. \& Hayes, W. (1968). Experiments in Microbial Genetics. Oxford and Edinburgh: Blackwell Scientific Publications.

Coetzee, J. N., Datta, N. \& Hedges, R. W. (1972). $\mathbf{R}$ factors from Proteus rettgeri. Journal of General Microbiology 72, 543-552.

DATTA, N. \& Hedges, R. W. (1971). Compatibility groups among $\mathrm{Fi}^{-} \mathrm{R}$ factors. Nature, London 234, 222-223.

DenHARDT, D. T. (1966). A membrane filter technique for detection of complementary DNA. Biochemical and Biophysical Research Communications 23, 641-646.

Falkow, S. (1975). Infectious Multiple Drug Resistance. London: Pion.

Gillespie, D. \& Spiegelman, S. (1965). A quantitative assay for DNA-RNA hybrids with DNA immobilized on a membrane. Journal of Molecular Biology 12, 829-842.

Grindley, N. D. F., Grindley, J. N. \& Anderson, E.S. (1972). R factor compatibility groups. Molecular and General Genetics 119, 287-297.

Grindley, N. D. F., HuMPhreys, G. O. \& ANDERSON, E. S. (1973). Molecular studies of $\mathbf{R}$ factor compatibility groups. Journal of Bacteriology 115, 387-398.

Guerry, P. \& Falkow, S. (1971). Polynucleotide sequence relationships among some bacterial plasmids. Journal of Bacteriology 107, 372-374.

Hedges, R. W. \& Datta, N. (1971). Fi- R factors giving chloramphenicol resistance. Nature, London 234, 220-221.

INGRAM, L. C., Richmond, M. H. \& Sykes, R. B. (1973). Molecular characterization of the $R$ factors implicated in the carbenicillin resistance of a sequence of Pseudomonas aeruginosa strains isolated from burns. Antimicrobial Agents and Chemotherapy 3, 279-288.
Kourilsky, Ph., Leidner, J. \& Tremblay, G. Y. (1971). DNA-DNA hybridization on filters at low temperature in the presence of formamide or urea. Biochimie 53, 1111-1114.

Kourilsky, Ph., Mercereau, O., Gros, D. \& Tremblay, G. Y. (1974). Hybridization on filters with competition DNA in the liquid phase in a standard and a micro-assay. Biochimie 56, 12151221.

Le Minor, L., Coynault, C., Chabbert, Y. A., Gerbaud, G. R. \& Le Minor, S. (1976). Groupes de compatibilité de plasmides métaboliques. Annales de Microbiologie (Institut Pasteur) 127B, 31-40.

Novick, R. P., Clowes, R. C., Cohen, S. N., Curtiss III, R., DatTa, N. \& Falkow, S. (1976). Uniform nomenclature for bacterial plasmids: a proposal. Bacteriological Reviews 40, 168-189.

Rahal, K., Gerbaud, G. R. \& Chabbert, Y. A. (1973). Caractérization d'un facteur de résistance transférable de Vibrio cholerae biotype el tor. Annales de Microbiologie (Institut Pasteur) 124B, 283-294.

Scavizzi, M. R. (1973). Nouveaux groupes d'incompatibilité des plasmides. Intérêt dans les épidémies de crêche à Escherichia coli 0111 :B4. Annales de Microbiologie (Institut Pasteu ) 124B, 153-167.

Shatkin, A. J. (1969). Colorimetric reactions of DNA, RNA and protein determination. In Fundamental Techniques in Virology, vol. 22, pp. 231237. Edited by K. Habel and N. P. Salzman. New York and London: Academic Press.

Smith, H. R., Grindley, N. D. F., Humphreys, G. O. \& ANDERSON, E. S. (1973). Interactions of group $\mathrm{H}$ resistance factors with the $\mathrm{F}$ factor. Journal of Bacteriology 115, 623-628.

Witchitz, J. L. (1975). Résistance enzymatiques aux aminosides et aminosides semi-synthétiques. Médicine et Maladies Infectieuses 5-6bis, 319-330.

Witchitz, J. L. (1977). Applications épidémiologiques de la classification des plasmides par incompatibilité. Thèse de Biologie Humaine, Paris.

Witchitz, J. L. \& Chabbert, Y. A. (1971). Résistance transférable à la gentamicine. I. Expression de la résistance. Annales de l'Institut Pasteur 121, 733-742.

Witchitz, J. L. \& ChabberT, Y. A. (1972). Résistance transférable à la gentamicine. II. Transmission et liaisons du caractère de résistance. Annales de l'Institut Pasteur 122-3, 367-378.

Wrtchitz, J. L. \& Gerbaud, G. R. (1972). Classification de plasmides conférant la résistance à la gentamicine. Annales de l'Institut Pasteur 123, 333-339. 